\title{
KESIAPAN PEMERINTAH SULAWESI SELATAN DALAM MENGHADAPI MASYARAKAT EKONOMI ASEAN 2015 DI BIDANG TENAGA KERJA PARIWISATA
}

\author{
Dede Rohman \\ rafael.haafi@gmail.com \\ Universitas Fajar Makassar
}

\begin{abstract}
Abstrak
Implementasi pilar ekonomi Komunitas ASEAN melalui Komunitas Ekonomi ASEAN (KEA), berdampak pada masuknya dan keluarnya tenaga kerja bebas di bidang pariwisata antar negara-negara ASEAN. Untuk mempersiapkan berlakunya AEC, daerah-daerah di seluruh Indonesia tentu saja memiliki struktur dan infrastruktur secara administratif harus disiapkan sesuai dengan ketentuan Mutual Recognition Arrangement (MRA) yang telah disepakati. Melalui otonomi daerah, pemerintah daerah memiliki kekuatan untuk meningkatkan kualitas sumber daya manusia lokal sehingga mereka dapat bersaing dengan negara anggota ASEAN lainnya, seperti menciptakan peraturan baru (peraturan daerah) yang terkait dengan KEA. Penelitian ini bertujuan untuk mengetahui kesiapan Pemerintah Sulawesi Selatan dalam mengantisipasi Komunitas Ekonomi ASEAN 2015 (KEA) dan mengidentifikasi faktor-faktor yang mendorong dan menghambat dalam menghadapi Komunitas Ekonomi ASEAN pada tahun 2015 di bidang kepegawaian pariwisata. Metode yang digunakan adalah deskriptif kualitatif, ditempuh melalui penggambaran masalah yang diteliti dalam validitas data informan yang memberikan informasi. Data diolah dan dianalisis dengan analisis kualitatif. Hasil penelitian menunjukkan kesiapan tenaga kerja pariwisata Sulawesi Selatan dalam menghadapi kekurangan kuantitas MEA memiliki tenaga kerja bersertifikat, lembaga sertifikasi, dan jumlah asesor. Secara kualitatif, peran pemerintah Sulawesi Selatan telah mengantisipasi pelaksanaan MEA melalui Perda No. 1 tahun 2011 yang berdampak pada peningkatan kualitas pariwisata. Kesempatan dalam menghadapi MEA yang relatif besar mendorong tenaga kerja pariwisata menyediakan pendidikan dan pelatihan berbasis kompetensi institusional yang besar sesuai dengan standar kerja yang disepakati dalam Mutual Recognition Arrangement (MRA) di MEA. Tantangannya karena kurangnya perhatian terhadap SKPD dalam proses sosialisasi dan percepatan sertifikasi profesional.
\end{abstract}

Kata kunci: Pemerintah Sulawesi Selatan, Komunitas Ekonomi ASEAN, Pariwisata, Ketenagakerjaan.

\section{ABSTRACT}

The implementation of the economic pillars of the ASEAN Community through an ASEAN Economic Community (AEC), effected on the incoming and outgoing labor freely in the field of tourism between ASEAN countries. To prepare for the enactment of the AEC, the regions throughout Indonesia must, of course, be administratively structural and infrastructure must be prepared in accordance with the agreed of Mutual Recognition Arrangement (MRA) provisions. Through regional autonomy, local governments have the power to raise the quality of local human resources so they can compete with other ASEAN member countries, such as creating new

$\mathrm{Halam}$ an $\mid \mathbf{1 4 4}$

Prodi Ilmu Hubungan Internasional FISIP UPN"Veteran" Jakarta 
regulations (local regulations) related to the AEC. The study aims to determine the readiness of the Government of South Sulawesi in anticipation of the 2015 ASEAN Economic Community (AEC) and identify factors driving and inhibiting in the face of the ASEAN Economic Community in 2015 in the field of tourism labor force. The method used is descriptive qualitative, pursued through the depiction of the issues examined in the validity of the data of informants who provide information. The data is processed and analyzed by qualitative analysis. The results showed the readiness of South Sulawesi tourism workforce in the face of a shortage in quantity MEA has certified workers, certification bodies, and the number of assessors. Qualitatively, the role of the South Sulawesi government has anticipated the implementation of MEAs through Perda No. 1 of 2011 which have an impact on improving the quality of tourism. Opportunities in the face of relatively large MEA boosted tourism labor supply large institutional competency based education and training according to the standard of work agreed upon during the Mutual Recognition Arrangement (MRA) in MEA. It Challenges from the lack of attention to the regional work units (SKPD) in the process of socialization and the acceleration of professional certification.

Keywords: Government of South Sulawesi, the ASEAN Economic Community, AEC, Tourism, Employment.

\section{Pendahuluan}

Sebagai sebuah wilayah, ASEAN yang tentunya menawarkan keanekaragaman yang kaya akan bakat, tradisi, sumber daya, dan kesempatan hidup sejahtera (Kotler, et.al 2007). Salah satu pilar utama dari ASEAN Community 2015, ASEAN Economic Community (AEC) yang lebih dikenal dengan Masyarakat Ekonomi ASEAN (MEA) merupakan pilar penting dalam proses integrasi negara anggota ASEAN (Anonym, 2013). Tujuan MEA ini untuk meningkatkan stabilitas perekonomian di kawasan Asia Tenggara serta perluasan dari integrasi ekonomi regional yang telah dimulai pada saat pembentukan AFTA pada tahun 1992 (Kemenlu RI, 2007). Selain itu, dengan terwujudnya MEA, dapat menjadikan posisi ASEAN menjadi lebih strategis di kancah internasional. Terwujudnya MEA ini dapat membuka mata semua pihak, sehingga terjadi suatu dialog antar sektor yang saling melengkapi diantara stakeholder ekonomi di negara-negara Asia Tenggara (Cipto, 2007).

MEA bertujuan untuk menghilangkan hambatan tarif dan membuka negosiasi komersial ASEAN melalui fungsi kekuasaan masyarakat sebagai "pasar tunggal" dan dunia "basis produksi". Tidak hanya akan ada bebasnya pergerakan 
barang dan investasi, tapi salah satu tujuan yang ditetapkan dalam Cetak Biru MEA adalah arus bebas tenaga kerja terampil, memungkinkan untuk dikelola secara missal atau terbukanya fasilitas dalam pergerakan orang secara alami dan terlibat dalam perdagangan lintas batas yang terkait dengan kegiatan investasi (Wailerdsak, 2013).

Beberapa karakteristik dan elemen, dari MEA seperti yang dijelaskan oleh ASEAN Economic Community Blueprint dalam 4 subpilar utama, yang pertama adalah menuju tercapainya Single Market dan Production Base bermakna bahwa arus perdagangan bebas untuk sektor barang, jasa, investasi, tenaga kerja profesional, modal, dan basis produksi (Kemenlu RI, 2010). Adapun proses pelaksanaan sub-pilar pertama, yaitu pencapaian liberalisasi dalamperdagangan barang, jasa, dan investasi sebagai realisasi Single Market dan Production Base. Skema MEA 2015 tentang jasa adalah memberlakukan liberalisasi tenaga kerja profesional seperti dokter, insinyur, akuntan, perawat, dokter gigi dan keahlian kerja lainnya. Keterkaitan keempat pilar MEA ini membutuhkan koordinasi konsistensi dan kesatuan arah elemen-elemen dari setiap pilar, dimulai dari perencanaan sampai dengan tahap implementasi. Untuk menjamin hal tersebut maka keempat pilar tersebut perlu didukung oleh komitmen kuat setiap negara anggota ASEAN (Wiyanto, 2008).

Dalam rangka menfasilitasi arus barang tenaga kerja terampil, hingga tahun 2009 ASEAN telah menyusun dan menyepakati beberapa Mutual Recognation Arrangament (MRA) yang diharapkan dapat menjembatani pergerakan arus tenaga kerja terampil secara bebas di wilayah ASEAN pada tahun 2016. Penyusunan dan pembahasan MRA tersebut dilakukan dalam pertemuan Sectoral Working Groups dibawah koordinasi Coordinating Commiteon Service (CCS). Sehingga pada tahun 2015 hanya tenaga kerja yang memiliki setifikat dan memenuhi standar MRA yang berpeluang mencari pekerjaan di negara-negara ASEAN (Kemenlu RI, 2010).

Dalam upaya mempersiapkan diberlakukannya MEA maka daerahdaerah diseluruh Indonesia tentunya, baik secara administratif struktural dan infrastuktur harus siap sesuai 
dengan ketentuan MRA yang telah disepakati. Melalui otonomi daerah, pemerintah daerah memiliki keleluasan wewenang guna mengangkat kualitas SDM lokal sehingga bisa bersaing dengan SDM negara-negara anggota ASEAN lainnya, seperti membuat regulasi baru (peraturan daerah) terkait MEA. Otonomi daerah pada dasarnya adalah hak, wewenang dan kewajiban daerah untuk mengatur dan mengurus rumah tangganya sendiri. Dimana, hak tersebut diperoleh melalui penyerahan urusan pemerintah dari pemerintah pusat kepada pemerintah daerah sesuai dengan keadaan dan kemampuan daerah yang bersangkutan (Djohermansyah, 2006).

Tenaga kerja adalah setiap orang yang mampu melakukan pekerjaan guna menghasilkan barang dan/atau jasa baik untuk memenuhi kebutuhan sendiri maupun untuk masyarakat (Agusmidah, 2010). Kebutuhan tenaga kerja di bidang pariwisata di Indonesia mencapai 2,9 persen atau sekitar 238 ribu dari jumlah kebutuhan totaltenagakerja (Anonym, 2014). Telah diberlakukannya Mutual Recognition Arrangement (MRA) pada 2016 maka persetujuan untuk mengakui dan menyamakan akreditasi yang dikelurakan negara untuk menjadi mitra mutlak harus dilaksanakan.

\section{Kerangka Pemikiran Metode Penelitian}

Tenaga kerja jasa pariwisata meliputi berbagai kategori, yaitu hotel dan restoran, spa, usaha perjalanan wisata, pramuwisata, jasa boga, MICE, pemandu wisata selam, pemandu ekowisata, pemandu wisata arung jeram dan pemandu museum. Adapun tenaga kerja di bidang pariwisata yang menjadi obyek penelitian adalah tenaga kerja pariwisata di Sulawesi Selatan, yaitu jasa Travel Agent, Hotel dan Restoran, serta Pemandu Wisata.

Batasan waktu penelitian hanya berkisar pada tahun 2009-2014. Hal ini dilakukan karena perkembangan ketenagakerjaan yang telah memiliki sertifikasi di bidang pariwisata di Sulawesi Selatan dalam 5 tahun kebelakang sangat kurang berkembang dan berkebalikan dengan pertumbuhan ekonomi Sulawesi Selatan yang signifikan. Dalam penelitian ini juga hanya membatasi pada pilar Masyarakat Ekonomi 
ASEAN (MEA) pada sub-pilar pertama bidang arus perdagangan bebas untuk sektor jasa pariwisata.

Penelitian membahas tentang fenomena liberalisasi ekonomi melalui MEA 2015 kaitannya dengan tenaga kerja bidang pariwisata di Sulawesi Selatan. Tujuan dari penelitian untuk mengetahui kesiapan Pemerintah Sulawesi Selatan dalam mengantisipasi ASEAN Community 2015 dan mengetahui faktor pendorong serta penghambatnya dalam menghadapi Masyarakat Ekonomi ASEAN (MEA) 2015 di bidang tenega kerja kepariwisataan.

Dengan jenis penelitian deskriptif, pendekatan yang digunakan adalah pendekatan kualitatif. Hal ini dimaksudkan untuk dapat memberikan gambaran atau mendeskripsikan secara sistematis, faktual dan akurat terhadap obyek yang diteliti. Menurut Sugiyono (2005), metode penelitian kualitatif adalah metode penelitian yang digunakan untuk meneliti pada kondisi obyek yang alamiah, (sebagai lawannya eksperimen) di mana peneliti adalah instrumen kunci, teknik pengumpulan data dilakukan secara triangulasi (gabungan), analisis data bersifat induktif dan hasil penelitian kualitatif lebih menekankan makna dari pada generalisasi.

Penelitian ini dilakukan di Provinsi Sulawesi Selatan (Sulsel), dimana secara tingkat pertumbuhan perekonomiannya lebih pesat dibandingkan dengan daerah lain di Indenesia dan memiliki obyek destinasi pariwisata menarik. Detail lokasi tempat penelitian di Provinsi Sulawesi Selatan terdiri dari instansi Pemerintah dan swasta yang memiliki keterkaitan erat dengan judul penelitian. Adapun instansi pemerintah, yaitu Pemerintah Provinsi Sulawesi Selatan, Dinas Kepariwisataan Sulawesi Selatan, dan Dinas Ketenagakerjaan.

Penelitian ini merupakan penelitian deskriptif kualitatif, dimana dalam menggambarkan permasalahan yang diteliti tergantung pada validitas data informan yang memberikan informasi dalam penelitian ini.Dalam penelitian ini menggunakan pendekatan Russett \& Starr dalam (Mas'oed, 2006) dengan melakukan pengumpulan data melalui: 1) dokumen, 2) rekaman arsip, 3) wawancara, dan 4) pengamatan langsung. 
Metode analisis data yang digunakan dalam penelitian ini adalah metode kualitatif, yaitu analisis data yang berupa kata-kata dan bukan rangkaian angka dengan berbagai cara pengumpulan data berupa observasi, wawancara, intisari dokumen, dan rekaman digital yang bisa diproses dan dianalisa berdasarkan teori dan konsep relevan yang selanjutnya disimpulkan.

\section{Perekonomian dan Tenaga Kerja}

\section{Kepariwisataan Sulawesi Selatan}

Provinsi Sulawesi Selatan memiliki konstribusi yang cukup signifikan bagi perkembangan perekonomian wilayah baik di kawasan kepulauan Sulawesi, Kawasan Timur Indonesia serta Indonesia. Posisi yang strategis sebagai Center of Indonesia serta peranannya sebagai pintu gerbang di kawasan Timur Indonesia sehingga mampu memberi akselerasi dan aksebilitas yang tinggi dalam wilayah. Dengan demikian, mudahnya lalu lintas manusia, barang, dan jasa menjadikan bidang pariwisata di Sulsel sebagai salahsatu destinasi unggulan setelah Bali di wilayah Timur Indonesia lebih berkembang dan maju.
Jaminan infrastruktur yang memadai untuk kegiatan bisnis dan investasi, ketersediaan potensi dan peluang investasi dari beragam komoditas di beberapa sektor usaha menjadikan Provinsi Sulawesi Selatan sebagai salah satu destinasi investasi yang prospektif bagi para pengusaha dan investor baik dari dalam maupun dari luar negeri. Selain dari kelengkapan tersebut diatas, dukungan yang kuat dari pemerintah Provinsi serta pemerintah Kabupaten/Kota dalam rangka peningkatan investasi melalui pemberian kebijakan yang pro investasi yang sejalan dengan kebijakan pemerintah Nasional akan memberi nilai lebih bagi para pengusaha dalam mempertimbangkan Provinsi Sulawesi Selatan sebagai daerah tujuan investasi potensial.

PDRB Sulawesi Selatan atas dasar harga berlaku pada tahun 2013 sekitar 184.783,06 milyar rupiah. Sektor pertanian mempunyai nilai tambah paling besar dibandingkan sektor lain yaitu mencapai 44.162,54 milyar rupiah. Selanjutnya disusul sektor perdagangan, hotel, restoran terbesar kedua dengan nilai tambah mencapai 33.031,58 milyar rupiah. Sektor industri pengolahan Sulawesi 
Selatan yang diharapkan mampu menunjang sektor pertanian dengan berorientasi pada agroindustri ternyata nilai tambahnya terbesar keempat, yaitu mencapai 22.559,13 milyar rupiah. Sementara PDRB Sulawesi Selatan atas dasar harga konstan 2000 pada tahun 2013 sebesar 64.284,43 milyar rupiah atau meningkat sekitar 7,65 persen, lebih tinggi dibandingkan dengan tahun 2012 (Lihat Tabel). ${ }^{2}$

2 Badan Koordinasi Penanaman Modal Daerah Provinsi Sulawesi Selatan, Perekonomian Daerah, Copyright (c) 2015 BKPMD SULSEL, pada situs http://bkpmd.sulselprov.go.id/?tpage=is\&i $\mathrm{d}=105$, diakses pada 20 Februari 2016. 
Tabel 1.

Perkembangan PDRB Sulawesi Selatan Tahun 2012-2013*)

\begin{tabular}{|c|c|c|c|c|c|}
\hline \multirow{2}{*}{ NO } & \multirow{2}{*}{ LAPANGAN USAHA } & \multicolumn{2}{|c|}{$\begin{array}{l}\text { HARGA BERLAKU } \\
\text { (Milyar Rupiah) }\end{array}$} & \multicolumn{2}{|c|}{$\begin{array}{l}\text { HARGA KONSTAN } 2000 \\
\text { (Milyar Rupiah) }\end{array}$} \\
\hline & & 2012 & 2013 & 2012 & 2013 \\
\hline 1. & Pertanian & $39.616,82$ & $44.162,54$ & $15.532,61$ & $16.145,48$ \\
\hline 2. & Pertambangan dan Penggalian & $8.961,89$ & $11.063,89$ & $4.290,20$ & $4.687,58$ \\
\hline 3. & Industri Pengolahan & $19.408,06$ & $22.559,13$ & $8.049,95$ & $8.703,87$ \\
\hline 4. & Listrik, Gas, dan Air Bersih & $1.439,21$ & $1.661,40$ & 647,52 & 701,63 \\
\hline 5. & Konstruksi & $9.071,24$ & $10.788,20$ & $3.567,25$ & $3.956,88$ \\
\hline 6. & $\begin{array}{l}\text { Perdagangan, Hotel, dan } \\
\text { Restoran }\end{array}$ & $28.748,16$ & $33.031,58$ & $10.661,44$ & $11.661,40$ \\
\hline 7. & $\begin{array}{l}\text { Pengangkutan } \\
\text { Komunikasi }\end{array}$ & $12.982,89$ & $14.867,28$ & $5.949,63$ & $6.480,21$ \\
\hline 8. & $\begin{array}{l}\text { Keuangan, Real Estat, dan } \\
\text { Jasa Perusahaan }\end{array}$ & $11.803,27$ & $14.584,81$ & $4.979,14$ & $5.685,01$ \\
\hline 9. & Jasa-jasa & $27.828,39$ & $32.064,22$ & $6.040,76$ & $6.262,38$ \\
\hline & PDRB & $159.859,93$ & $184.783,06$ & $59.718,50$ & $64.284,43$ \\
\hline
\end{tabular}

*) Sumber:

http://bkpmd.sulselprov.go.id/?tpage=is\&id=105 
Kegiatan perdagangan di Provinsi Sulawesi

Selatan dengan menggunakan indikator nilai ekspor dan impor pada tahun 2014 memperlihatkan terjadinya kenaikan pada nilai ekspor dan penurunan pada nilai impor. Hal ini terlihat dari kinerja ekspor Sulawesi Selatan pada tahun 2014 sebesar US\$. 1,75 juta, mengalami peningkatan dibanding tahun sebelumnya sebesar US\$ 1,58 juta sementara untuk nilai impor pada tahun 2014 sebesar US\$. 836,22 ribu menurun dibanding tahun 2013 yang bernilai US\$. 1,36 juta.

Dalam bidang pariwisata, ditengah perlambatan ekonomi dunia dewasa ini, Sulawesi Selatan mengalami pertumbuhan ekonomi yang signifikan. Dalam tahun 2014, sektor pariwisata menyumbang 36.19 \% terhadap PDRB Sulawesi Selatan, dihitung dari berbagai sumber terkait dengan pariwisata seperti Hotel/Restoran, Transportasi, Perdagangan, Souveneer.

Menurut staf pegawai BPS Bapak Awaluddin, dalam kurun waktu semester pertama tahun 2014 PDRB Sulawesi Selatan yakni $8 \%$ persen. Menariknya, pertumbuhan ini sebagai pemicu terbesar berdadasar urutannya yang pertama adalah sektor perdagangan, hotel dan restoran yakni $12,12 \%$, kedua adalah sektor angkutan dan komunikasi yakni 11,65 $\%$, dan ketiga adalah sektor keuangan, real estate dan perusahaan yakni 11,12 \%. Disini terlihat bahwa bagaimana kuatnya pemicu sektor perhotelan dan restoran di Sulawesi Selatan sebagai penyumbang perekonomian daerah.

Upaya membangun pariwisata Sulawesi Selatan dengan program Lovely December walaupun dilaksanakan dalam bentuk crash programe telah memberi warna tersendiri dalam aspek Positioning wilayah Sulawesi Selatan. Dalam aspek daya saing antar destinasi baik internasional, regional, maupun nasional yang akan dilanjutkan dengan program lanjutan sampai tahun 2016 diharapkan pariwisata Sulawesi Selatan dengan Brand Toraja menjadi perhatian internasional dan pembangunan Centre Point of Indonesia. Di Kota Makassar, untuk menuju kearah tersebut pada tahun 2012 hingga 2015 telah dilaksanakan berbagai even nasional dan Internasional dalam mendukung program Visit South Sulawesi 
Sulawesi". Makassar dicanangkan sebagai Kota Tujuan wisata MICE (konfrensi, pertemuan dan pameran) yang masih memiliki kekurangan 2.500 kamar hotel dan 5000 ruang pertemuan (meeting) untuk menampung wisatawan maupun peserta perhelatan dan pameran.

Peletakan dasar pengembangan pariwisata di Sulawesi Selatan diawali dengan program Lovely December 2008 merupakan awal dari strategi pengembangan yang saat ini terus digalakkan. Penataan pengembangan pariwisata dengan model pengembangan cluster yang didasarkan atas kesamaan produk dan kedekatan wilayah, pendekatan ini memberi ruang bagi upaya optimalisasi pelayanan kepariwisataan di Sulawesi Selatan.

Kunjungan wisman dan wisnus ke Sulawesi Selatan menunjukkan grafik peningkatan signifikan baik dari jumlah wisatawan maupun pengeluaran yang secara langsung berkorelasi positif terhadap industri pariwisata di Sulawesi Selatan. Hal diatas tercermin dari meningkatnya tingkat hunian kamar hotel di Kota Makassar dengan aktifitas MICE.
Demikian halnya dengan aksesibilitas dalam hal ini Bandara Sultan Hasanuddin saat ini memiliki performance yang sangat memadai termasuk dapat diakses langsung melalui Kualalumpur melalui Air Asia. Hal ini menjadi pembuktian, dengan tersedianya penerbangan internasional dari berbagai Negara ke Bandara Sultan Hasanuddin Makassar. Menurut BPS, angka kunjungan melalui pintu masuk Bandara Sultan Hasanuddin meningkat tajam sebesar $46 \%$ pada tahun 2008, yang merupakan peningkatan terbesar diantara 15 pintu masuk. Tahun 2014 Pemerintah propinsi Sulawesi Selatan telah menjajaki maskapai penerbangan asing untuk menarik wisatawan Singapura melalui Tiger Air dengan rute langsung dari Singapura ke Makassar. Pada tahun 2013 telah terrealisasi penerbangan langsung oleh Silk Air anak perusahaan Singapore Airlines Makassar - Singapura dan telah melakukan kerjasama dengan penerbangan domestik membuka jalur baru Makassar - Kuala Lumpur dan Makassar - Singapura (PP).

Tersedianya aksesiblitas melalui Bandara Internasional Sultan Hasanuddin berimplikasi langsung 
terhadap target kunjungan wisatawan.

Bandara Internasional Sultan

Hasanuddin data dilansir dari Angkasa

Pura I Makassar menunjukkan pada tahun 2014, lalu lintas penumpang yang masuk melalui Bandara ini sebesar 7.455.405 orang baik jumlah kedatangan maupun keberangkatan atau naik $7 \%$ dari tahun sebelumnya. Adapun rerata penumpang yang tiba sebanyak 2.952.272 dan penumpang berangkat 2.705.736 sedangkan transit sebesar 1.797.397 jumlah total 7.455.408 atau naik $11 \%$ dibanding tahun 2013. Bandara Internasional Sultan Hasanuddin setiap harinya melayani \pm 200 unit pesawat besar maupun kecil dari 15 kota besar di Indonesia. Prasarana dan fasilitas Bandara Sultan Hasanuddin juga merupakan jalur penerbangan di Indonesia dari dan ke kawasan barat \& timur Indonesia, dan termasuk bandar udara tersibuk dengan memiliki landasan sepanjang 2.500 meter yang dapat dilandasi pesawat berbadan lebar (airbus).

Pintu masuk melalui pelabuhan laut, Sulawesi Selatan merupakan satu-satunya Propinsi di Indonesia yang memiliki 3 pelabuhan, pelabuhan Sukarno-Hatta Makassar sebagai hub perjalanan wisatawan kapal pesiar yang ingin menikmati Kota Makassar dengan wisata kulinernya, pelabuhan Parepare sebagai hub wisatawan kapal pesiar menjelajahi jazirah bugis (Kabupaten Sidrap, Soppeng dan Bone), serta pelabuhan Palopo sebagai hub perjalan wisata tamu kapal pesiar yang akan menikmati paket wisata ke Tana Toraja.

Pada era dibukanya pasar barang dan jasa tingkat ASEAN, maka keluar-masuknya tenaga kerja antar negara ASEAN tidak terbendung lagi dalam berkompetisi merebut kesempatan kerja di tiap negara anggota ASEAN. Hal ini dikarenakan ASEAN telah menyutujui standar tenaga kerja profesional, sebagai standar tenaga kerja yang akan direalisasikan pada MEA 2016 mendatang. Kebijakan pemerintah pusat sangat menentukan nasib kualitas tenaga kerja Indonesia, terutama di pelosok daerah.

Kepala Dinas Pariwisata Sulawesi Selatan H. Jufri Rahman menjelaskan, pertumbuhan kunjungan wisatawan mancanegara dan wisatawan nusantara di Sulawesi Selatan rata-rata 20 - 30 persen per tahun. Berdasarkan data Dinas 
Pariwisata Sulsel diketahui, jumlah Wisman tercatat 64.601 orang dan Wisnu 4.871.966 orang pada periode 2012. Sedangkan pada 2013 wisman 106.584 orang dan wisnu 5.385.809 orang. ${ }^{3}$ Demikian pula daya serap terhadap tenaga kerja pariwisata makin tinggi, tidak hanya oleh pelaku industri di dalam negeri, tapi juga oleh industri pariwisata dari luar negeri.

Jumlah tenaga kerja pariwisata yang tersertifikasi di Indonesia baru sekitar $6,7 \%$ dibandingkan dengan serapan tenaga kerja di sektor formal yang mencapai 3 juta jiwa. Meskipun jumlah tersebut melampui target yang ditetapkan pemerintah sebanyak 50.000 orang, tetapi angka tersebut masih sangat terbatas dibandingkan dengan serapan tenaga kerja pariwisata. Jika ditambah dengan sertifikasi yang dihasilkan Lembaga Sertifikasi Profesi (LSP), sekolah kepariwisataan dan manajemen perhotelan, jumlah tenaga kerja tersertifikasi yang sesuai dengan Peraturan Pemerintah No.52/2012 tentang Sertifikasi Kompetensi dan Sertifikasi Usaha di Bidang Pariwisata mencapai sekitar 200.000 orang atau 6,67\% dibandingkan dengan asumsi serapan tenaga kerja pariwisata di sektor formal yang mencapai 3 juta jiwa.

Tahun 2013, Sulawesi Selatan memiliki 280 pemandu wisata yang berlisensi menengah (madya) menurut data Himpunan Pramuwisata Indonesia. Jumlah tersebut sangat sedikit dibanding jumlah keseluruhan pemandu wisata yang tidak memiliki lisensi dari Dinas Pariwisata Provinsi maupun lisensi pemula dari kabupaten/kota. Meski ada UndangUndang Pariwisata No.10 Tahun 2009, namun tidak bisa dikenakan sanksi karena belum adanya Perda.

Proses liberalisasi yang tengah berjalan dalam perekonomian dunia saat ini membuka peluang adanya kompetisi bisnis atau usaha yang lebih transparan dengan mengandalkan peran tenaga kerja yang kompeten dan profesional di bidangnya sebagai daya saing. Di bidang pariwisata, tenaga kerja yang kompeten dan profesional tentunya akan meningkatkan daya saing serta melindunginya bila bekerja di kawasan regional maupun internasional.

Liberalisasi yang arahnya menuju kepada sistem lebih terbuka, transparan, dan digerakan oleh 
mekanisme pasar ini pada prosesnya akan menuntut kita untuk dapat membangun komitmen bersama tentang pentingnya standarisasi dan sertifikasi bidang pariwisata. Sehingga hal tersebut dapat menciptakan sumber daya manusia (SDM) bidang pariwisata yang mampu berkiprah di tingkat nasional maupun internasional. Dengan berlakunya standar kompetensi dalam ketenagakerjaan di bidang pariwisata pada gilirannya akan meningkatkan kualitas produk dan pelayanan kita di bidang pariwisata.

Era baru fenomena perdagangan bebas dalam masyarakat internasional, menjadikan ASEAN Community 2015 sebagai peluang sekaligus tantangan bagi Indonesia terutama kesiapan pemerintah daerah, khususnya Sulawesi Selatan guna menghadapi era liberalisasi tentang ketenagakerjaan di bidang pariwisata. Berdasar pada hal inilah, penulis mencoba meneliti fenomena liberalisasi ekonomi melalui MEA 2015 kaitannya dengan tenaga kerja bidang pariwisata di Sulawesi Selatan.

\section{Kesiapan Tenaga Kerja Pariwisata}

Hasil penelitian menunjukkan kesiapan tenaga kerja pariwisata Sulawesi Selatan dalam menghadapi MEA memiliki kekurangan secara kuantitas pekerja tersertifikasi, lembaga sertifikasi, dan jumlah assessor. Namun secara kualitatif, peran pemerintah Sulawesi Selatan telah mengantisipasi diberlakukannya MEA melalui Perda No. 1 tahun 2011 yang berdampak kepada peningkatan kualitas tenaga pariwisata. Berikut beberpa faktor yang mendukung kesiapan pemerintah Sulsel dalam menghadapi MEA di bidang ketenagakerjaan jasa pariwisata.

Pertama, kualitas SDM Pariwisata yang tersertifikasi. Berdasarkan penelusuran data di dinas tenaga kerja dan transmigrasi Propinsi Sulwesi Selatan, tidak di temukan data yang memadai berkenaan dengan sumberdaya manusia di bidang pariwisata. Namun terdapat data pekerja pada sektor hotel dan restoran pada tahun 2014, yakni 26.579 pekerja terbagi atas; 17.616 pekerja sektor perhotelan dan 8.963 pekerja sektor restoran dan rumah makan. Pada awalnya, hal ini cukup menyulitkan peneliti dalam mendapatkan data faktual untuk menggambarkan kondisi pekerja sektor pariwisata di sulwesi 
selatan selanjutnya peneliti mengadakan penelusuran data di dinas kebudayaan dan kepariwisataan Propinsi Sulawesi Selatan sebagai leading sektor terkait langsung dengan tenaga kerja di bidang pariwisata. Setelah penelusuran data dilakukan maka di dapatkan data tenaga kerja terkait sektor pariwisata yang sudah diolah oleh LSP (Lembaga Sertifikasi Profesi) yang menjadi mitra dinas kebudayaan dan kepariwisataan yakni LSP Anging Mammiri.

Dari figur data yang diteliti pada tabel 1 (terlampir) terlihat bahwa tenaga kerja sector pariwisata pada tahun 2014 baru terdata 77.008 pekerja pariwsata. Berdasarkan laporan dari asosiasi profesi terkait sektor pariwisata yang terdiri dari sembilan asosiasi telah mendapat sertifikasi profesi baik dari Lembaga Sertifikasi Profesi maupun Instansi terkait selaku Pembina dari lingkup profesi tertentu. Asosiasi pariwisata PHRI (Perhimpunan Hotel dan Restoran Indonesia) se-Sulawesi Selatan memiliki karayawan paling banyak diantara 8 asosiasi lainnya sebanyak 37.000 pekerja, akumulasi dari 15.000 pekerja tersertifikasi dan 22 pekerja belum tersertifikasi. Data tersebut juga terungkap total pekerja yang tersertifikasi jumlahnya jauh lebih kecil dari yang belum tersertifikasi bila di rata-ratakan prosentasenya hampir mencapai 60 persen belum mendapatkan sertifikasi. Hal ini bila di generalisasi bagaimana kondisi pekerja pariwisata Sulawesi Selatan dalam menghadapi MEA di level pekerja bawah dan menengah tentunya belum siap menghadapi serbuan pekerja asing dari negaranegara anggota ASEAN terutama pekerja pariwisata dari Philipina dan Vietnam serta Thailand.

Faktor kedua adalah kesiapan lemebaga sertifikasi profesi sebagai assessor yang akan melakukan asessmen terhadapi keahlian dan keterampilan para pekerja pariwisata. Hal ini sangat krusial karena telah disepakatinya penerapan standar ASEAN MRA Tourism Professional. Mewajibkan para pekerja pariwisata untuk memenuhi standart pekerja profesional pariwisata ASEAN dimana peran para assesor tersertifikasi akan menentukan kualifikasi sesuai ASEAN Common Competency Standards for Tourism Professionals/ ACCSTP) dari para pekerja parwisata. 
Berdasarkan penelusuran data

di dinas kebudayaan dan kepariwisataan propinsi Sulwesi Selatan baru terdapat 2 lembaga sertifikasi profesi pariwisata yang terakreditasi oleh BNSP yakni LSP Anging Mammiri yang difasilitasi oleh dinas kebudayaan dan kepariwisataan Propinsi Sulawesi Selatan dan LSP Phinisi yang di fasilitasi oleh Dinas Parwisata dan Ekonomi Kreatif Kota Makassar dan institusi pendidikan (AKPAR Makassar dan sejumlah SMK Pariwisata yang memiliki assessor yang tersertifikasi) dan para Profesional dari para Manager Hotel Restoran serta Biro Perjalanan yang telah di sertifikasi oleh kementerian Pariwisata.

Jika dibandingkan dengan skema job titles dalam MRA MEA, maka dari keseluruhan 32 jobtitle tersebut dalam tabel 2 (terlampir), hampir telah terakomodir dalam Standar Kompetensi Kerja Nasional Indonesia (SKKNI). Dengan demikian, para alumni dari lembaga pendididkan (SMK Pariwisata dan Politeknik Pariwsata) telah siap dan memilliki kompetensi dasar yang di butuhkan untuk bersaing dengan pekerja dari negara-negara ASEAN lainya dalam MEA. Bahkan sejak tahun 2000 alumni-alumni AKPAR Makassar telah mampu bersaing di bursa kerja asia dan eropa dimana beberapa diantaranya mempu menempati posisi manajer di beberapa jaringan hotel internasional di negara ASEAN, seperti Malayasia dan Vietnam.

Adapun faktor ketiga adalah kebijakan pemerintah. Secara umum, kebijakan mengenai ketenagakerjaan tercantum dalam road map pengembangan SDM Sulawesi Selatan tahun 2012-2017. Dijelaskan dalam road map tersebut bahwa pengembangan SDM Sulawesi Selatan mengacu pada RJPMD dan pelaksanaanya berkordinasi dengan lintas sektor yang terkait, seperti Dinas Kabupaten/Kota di wilayah Sulawesi Selatan. Khususnya Dinas Kebudayaan dan Kepariwisataan Propinsi Sulawesi Selatan melalui Perda No. 1 tahun 2011 Tentang Penyelenggaraan Kepariwisataan di Sulawesi Selatan Bab XIII Tentang Sumberdaya Manusia Standarisasi Sertifikasi dan Tenaga Kerja (tenaga kerja ahli warga negara asing), pasal $35,36,37,39$ dan 40 sebagai 
kebijakan proteksi awal bagi tenaga kerja pariwisata lokal dalam dalam menghadapi masuknya tenaga kerja asing. Selain itu, DISBUDPAR bekerjasama dengan kementerian Pariwisata dan kabupaten Kota seSulawesi Selatan melakukan sosialisasi/ pelatihan dan standarisasi serta sertifikasi dari para pekerja sektor pariwsata untuk meningkatkan profesionalisme SDM hingga dapat bersaing dengan tenaga kerja asing.

Peluang dalam menghadapi MEA relatif besar di dukung suplay tenaga kerja pariwisata yang besar dari institusi pendidikan dan pelatihan berbasis kompetensi sesuai standar pekerjaan yang disepakati dalam Mutual Recognation Arrangement (MRA) MEA. Tantangan berasal dari lemahnya perhatian Satuan Kerja Perangkat Daerah (SKPD) dalam proses sosialisasi dan percepatan sertifikasi profesi.

\section{Analisis Penelitian}

Penelitian ini mununjukkan bahwa pada tahun 2014, sebanyak 77.008 pekerja pariwsata berdasarkan laporan dari asosiasi profesi terkait sektor pariwisata yang telah mendapat sertifikasi profesi baik dari Lembaga Sertifikasi Profesi maupun instansi terkait selaku pembina dari lingkup profesi tertentu. Dari data tersebut juga terungkap pekerja yang tersertifikasi jumlahnya jauh lebih kecil dari yang belum tersertifikasi bila di rata-ratakan prosentasenya hampir mencapai 60 persen belum mendapatkan sertifikasi. Hal ini bila di generalisasi bagaimana kondisi pekerja pariwisata Sulsel dalam menghadapi MEA di level pekerja bawah dan menegah tentunya belum siap menghadapi serbuan pekerja asing dari negara-negara anggota Asean terutama pekerja pariwisata dari Philipina dan Vietnam serta Thailand. Hal ini juga di akui Wakil Gubernur Sulawesi Selatan, bahwa Sumber Daya Manusia (SDM) Sulawesi Selatan diakui sebagai satusatunya sektor yang belum sepenuhnya siap menghadapi MEA. Kendati begitu, SDM tetap menjadi fokus utama yang akan terus ditingkatkan kualitasnya. Wakil Gubernur Sulawesi Selatan, Agus Arifin Numang dalam wawancara menjelaskan, dibandingkan dengan Sumber Daya Alam (SDA) yang melimpah, minimnya SDM berkualitas membuat kekayaan SDA tidak semua bisa dikelolah maksimal 
dan SDM, “...yang mengolah ini masih sangat kurang. Permasalahan ini harus segera ada perbaikan, jangan sampai SDM yang mengelola datang dari luar Sulawesi Selatan,"

\section{Pariwisata menjadi faktor}

penting dalam pengembangan ekonomi karena kegiatannya mendorong perkembangan beberapa sektor ekonomi nasional. Salah satu faktornya ialah dapat memberi dampak positif pada tenaga kerja di negara, karena pariwisata memperluas lapangan kerja baru dan tugas baru di hotel atau di tempat penginapan lainnya, usaha perjalanan, di kantorkantor pemerintah yang mengurus pariwisata-pariwisata dan penerjemah, industri kerajinan tangan dan cenderamata, serta tempat-tempat penjualan lainnya (Yoety, 2010).

Pentingnya kesiapan lembaga sertifikasi profesi sebagai assessor yang akan melakukan asessmen terhadap keahlian dan keterampilan para pekerja pariwisata sangat dibutuhkan. Karena telah disepakatinya standar ASEAN MRA Tourism Professional yang mewajibkan para pekerja pariwisata untuk memenuhi standar pekerja profesional pariwisata ASEAN.Peran para assesor tersertifikasi akan menentukan kualifikasi sesuai ASEAN Common Competency Standards for Tourism Professionals/ ACCSTP) dari para pekerja parwisata. Berdasarkan penelusuran data di dinas kebudayaan dan kepariwisataan propinsi Sulwesi Selatan baru terdapat 2 lembaga sertifikasi profesi pariwisata yang terakreditasi oleh BNSP yakni LSP Anging Mammiri yang difasilitasi oleh dinas kebudayaan dan kepariwisataan Propinsi Sulawesi Selatan dan LSP Phinisi yang di fasilitasi oleh Dinas Parwisata dan Ekonomi Kreatif Kota Makassar dan institusi pendidikan (AKPAR Makassar dan sejumlah SMK Pariwisata yang memiliki assessor yang tersertifikasi) dan para Profesional dari para Manager Hotel Restoran serta Biro Perjalanan yang telah di sertifikasi oleh kementerian Pariwisata.

Dari data yang di analisis peneliti jumlah asessor yang tersertifikasi oleh kementerian pariwisata di Sulawesi Selatan terdapat total 84 orang asessor di bidang pariwisata terdiri dari: 24 di Bidang Restoran, 35 Bidang Hotel, 20 di bidang Biro Perjalana Wisata, dan 5 
di Pramuwisata. Jumlah ini sangat minim jika dimanfaatkan untuk mengakselerasi sertifikasi pekerja pariwisata di Sulawesi Selatan. Walaupun secara nasional para asessor dan lembaga sertifikasi parwisata dari luar dapat melakukan kegiatan asessment di Sulawesi Selatan tentunya akan berdampak pada pembiayaan kegiatan asessementyang semakin mahal dengan asumsi untuk meng-asesmen 1 pekerja pariwisata (Perhotelan/restoran) di butuhkan biaya kurang lebih 1,5 juta rupiah. Hal tersebut menjadi salah satu sebab minimnya para pengusaha dan pekerja untuk melakukan sertifikasi profesi, yang tentunya akan berpengaruh terhadap kualitas dan kesiapan sumber daya manusia Sulawesi Selatan secara makro.

Secara umum, kebijakan mengenai ketenagakerjaan sudah tercantum dalam road map pengembangan SDM Sulawesi Selatan tahun 2012-2017. Dijelaskan dalam road map tersebut bahwa pengembangan SDM Sulawesi Selatan mengacu pada RJPMD dan pelaksanaanya berkooredinasi dengan lintas sektor yang terkait, seperti Dinas Kabupaten/Kota di wilayah
Sulawesi Selatan. Khususnya Dinas Kebudayaan dan Kepariwisataan Propinsi Sulawesi Selatan melalui Perda No. 1 tahun 2011 Tentang Penyelenggaraan Kepariwisataan Di Sulawesi Selatan Bab XIII Tentang Sumberdaya Manusia Standarisasi Sertifikasi dan Tenaga Kerja (tenaga kerja ahli warga negara asing), pasal $35,36,37,39$ dan 40 sebagai kebijakan proteksi awal bagi tenaga kerja pariwisata lokal dalam dalam menghadapi masuknya tenaga kerja asing. Selain itu, DISBUDPAR bekerjasama dengan kementerian Pariwisata dan kabupaten Kota seSulawesi Selatan melakukan sosialisasi/ pelatihan dan standarisasi serta sertifikasi dari para pekerja sektor pariwsata untuk meningkatkan profesionalisme SDM hingga dapat bersaing dengan tenaga kerja asing.

Sektor industri di Sulawesi Selatan yang mampu bersaing dalam menghadapi MEA 2015, adalah sektor yang bergerak di bidang pariwisata. Sektor pariwisata memiliki potensi dalam di dunia pariwisata internasional. Potensi yang dimiliki Sulawesi Selatan dapat dilihat dari daya saing yang terus membaik, terutama untuk kategori budaya 
(cultural and heritage), sumber daya alam (rich natural resource) dan harga (value for money). Peluang lainnya adalah dengan semakin membaiknya pariwisata ASEAN akan mendorong meningkatkan kunjungan wisatawan mancanegara dari kawasan ASEAN ke Negara anggota termasuk Indonesia, khususnya daerah Sulawesi Selatan. Hal ini seiring diberlakukannya single destination and common visa ASEAN Sumber daya manusia Sulawesi Selatan memiliki suplai tenaga kerja pariwisata yang sudah di kenal kompetensinya. Sejak tahun 1998 SMK Parwisata di Sulawesi Selatan telah merintis program magang internship di beberapa jaringan Hotel internasional, seperti Novotel, Accord Asia Pasific, Melia Internasional, Sheraton dan hotel-hotel internasional di kawasan Asia Pasifik. Sejak saat itu tenaga kerja pariwisata sektor perhotelan asal Sulawesi Selatan tidak canggung dan mampu bersaing dengan sumber daya manusia berasal dari luar negeri. Ada pula lulusan akademi pariwisata dan lembaga pelatihan perhotelan seperti Quality Hotel Grup yang langsung mampu di serap bursa kerja lokal hingga internasional.
Tantangan terbesar dalam mengahadapi era MEA adalah regulasi dan kebijakan yang mampu melindungi pekerja lokal dari serbuan pekerja asing, dimana saat ini pekerjapekerja parwisata asal Philipina, Vietnam, Myanmar, Thailand sudah mulai membekali diri dengan penguasaan bahasa Indonesia. Pengaruh diberlakukannya MEA akan memberi dampak kepada Sulawesi Selatan terhadap arus tenaga kerja asing yang akan menempati posisiposisi kunci dalam manajemen hingga front liner.

Tidak adanya sinergitas antar dinas terkait dalam merumuskan program dan kebijakan terkait pengembangan dan perlindungan SDM lokal, juga dalam mempercepat proses sertifikasi para pekerja pariwisata sebagai tujuan utama dalam menghadapi era bursa kerja yang terbuka di era MEA. Hal ini harus segera mendapatkan perhatian serius dari SKPD terkait terutama dinas tenaga kerja dan transmigrasi yang sangat terkesan statis terpaku pada roadmap pengembangam sumberdaya manusia yang tercantum dalam RPJPMD Propinsi Sulawesi Selatan. 
Selanjutnya, kurangnya

perhatian para legislator dalam menginisiasi regulasi tentang perlindungan tenaga kerja lokal dan pengembangan sumberdaya manusia di wilayah Sulawesi Selatan menjadi salah satu penyebab ketidaksiapan menghadapi MEA. Hal ini terbukti tidak adanya policy yang di dorong oleh pihak legislatif untuk memaksa pemerintah daerah mempersiapkan SDM Sulawesi Selatan menghadapi MEA.

\section{Kesimpulan dan Saran}

Berdasarkan tujuan penelitian, maka dapat disimpulkan bahwa pemerintah Sulawesi Selatan telah siap dalam mengantisipasi ASEAN Community 2015 pada pilar ekonomi.

\section{Hal tersebut ditunjang dengan} terlaksananya beberapa faktor pendorong yang dapat menekan faktor penghambat dalam menghadapi Masyarakat Ekonomi ASEAN (MEA) 2015 di bidang tenega kerja kepariwisataan.

Hasil penelitian ini menjelaskan bahwa kesiapan tenaga kerja Sulawesi Selatan dalam menghadapi MEA dapat di ukur dari beberapa parameter utama yakni:
Pertama, kesiapan sumber daya manusia yang di nilai masih kurang dari kuantitas jumlah pekerja yang tersertifikasi. Kedua, dari segi lembaga sertifikasi dan assesor yang jumlah sangat minim dibanding suplay tenaga kerja pariwisata hal ini tentu berpengaruh dalam proses sertifikasi sebagai pra-syarat untuk kesiapan tenaga kerja. Ketiga, kebijakan pemerintah yang belum sinkron dalam upaya pengembangan dan perlindungan SDM lokal. Keempat, peluang Sulawesi Selatan pada bidang tenaga kerja parwisatacukup besar, dengan di dukung suplay tenaga kerja pariwisata yang besar dari institusi pendidikan dan pelatihan berbasis kompetensi, penerapan kurikulum berbasis kompetensi yang sinkron dengan SKKNI dan Jobtitles yang tercantum dalam MRA - AEC. Kelima, lemahnya perhatian SKPD terkait dalam proses sosialisasi dan percepatan sertifikasi profesi melahirkan strategi dari pemetrintah Sulawesi Selatan melalui kebijakan Gerakan Akselerasi Sertifikasi Tenaga Kerja Pariwisata se-Sulawesi Selatan.

Adapun saran penulis antara lain: Pertama mendukung percepatan akselerasi serifikasi sertifikasi pekerja 
pariwisata Sulawesi Selatan dalam menghadapi MEA diperlukan payung hukum yang harus di inisiasi oleh pemerintah bersama legislator melalui peraturan daerah yang diikuti regulasi pendukung berupa Peraturan Gubernur, Peraturan Walikota, Peraturan Bupati di tingkat daerah; Kedua perlunya sinergi antara pemerintah propinsi dan Kabupaten/Kota se-Sulawesi Selatan agar gerakan ini dapat maksimal memberdayakan para pekerja pariwisata melalui sertifikasi kompetensiprofesi yang juga sekaligus upaya proteksi terhadap sumberdaya manusia di daerah; Ketiga, perlunya persamaan persepsi dan tindakan holistik antara stakeholders dalam mempercepat peningkatan kompetensi SDM dalam menghadapi MEA melaui proses sertifikasi kompetensi berada di hilir, hulunya adalah SKKNI, KKNI, PBK yang ditetapkan oleh sektor pariwisata dan stakeholder-nya.

\section{DAFTAR PUSTAKA}

Agusmidah. (2010). Dinamika Hukum Ketenagakerjaan Indonesia. Medan: USU Press

Anonim. (2014) Kebutuhan Tenaga Kerja Pariwisata Terus Meningkat, dalam situs: http://grahawisatanusantara.com /berita-141-kebutuhan-tenagakerja-pariwisata-terusmeningkat.html

Anonim. Introduction of ASEAN Economic Community/AEC. (2013) dalam: http://www.asean.org/communiti es/asean-economic-community

Badan Koordinasi Penanaman Modal Daerah Provinsi Sulawesi Selatan, Perekonomian Daerah, Copyright (C) 2015 BKPMD SULSEL, pada http://bkpmd.sulselprov.go.id/?tp age $=$ is\&id $=105$.

Cipto B. (2007). Hubungan Internasional di Asia Tenggara. Yogyakarta: Pustaka Pelajar. hal. 247.

Djohermansyah D. (2006). Problematik Pemerintahan dan Politik Lokal. Jakarta: Bumi Aksar.

Kemenlu RI. (2007). ASEAN Selayang Pandang. Jakarta: DIRJEN Kerjasama ASEAN DEPLU RI.

Kemenlu RI. (2010). Cetak Biru Komunitas Ekonomi ASEAN. Jakarta: DIRJEN Kerjasama ASEAN DEPLU RI.

Kotler P. (2007). Think ASEAN! Rethinking Marketing toward ASEAN Community 2015. Singapore: Mc. Graw Hill.

Mas'oed M. (2006). Ilmu Hubungan Internasional: Disiplin dan Metodologi. Jakarta: LP3ES. 
Pertumbuhan Kunjungan Wisata Sulsel Capai 30 Persen, oleh Suriani Mappong, http://www.antarasulsel.com/ber ita/54563/pertumbuhankunjungan-wisata-sulsel-capai30-persen

Sugiyono. (2005). Memahami Penelitian Kualitatif. Bandung: Alfabeta.

Sulsel Miliki 280 Pemandu Wisata Berlisensi

http://antarasulawesiselatan.com /print/ 24076/sulsel-miliki-280pemandu-wisata-berlisensi

Wailerdsak N. (2013). Impacts of Asean (Association of South East Asian Nations) Economic Community on Labour Market and Human Resource Management in Thailand. South East Asia Journal of Contemporary Business,
Economics and Law (e-journal). Vol. 2, Issue 2, 2013 - June.

Wiyanto R. dkk. (2008). Masyarakat Ekonomi ASEAN 2015. Jakarta:

PT. Alex Media Komputindo KOMPAS Gramedia.

Yoeti O.A. (2010). Dasar-Dasar Pengertian Hospitality dan Pariwisata. Bandung: PT. Alumni. 